\title{
Removal of Escherichia coli from biological effluents using natural and artificial mineral aggregates
}

\author{
M Miranda-Ríos', VM Luna-Pabello1*, MT Orta de Velásquez ${ }^{2}$ and JA Barrera-Godínez ${ }^{1}$ \\ ${ }^{1}$ Facultad de Química, Universidad Nacional Autónoma de México, Ciudad Universitaria, México D. F. 04510, México \\ ${ }^{2}$ Instituto de Ingeniería, Universidad Nacional Autónoma de México, Ciudad Universitaria, México D. F. 04510, México
}

\begin{abstract}
Ability for disinfecting sterile biological effluents inoculated with Escherichia coli ATCC 25922 at concentrations of $10^{5} \mathrm{CFU} / \mathrm{m} \ell$, using a natural mineral aggregate (NMA) and artificial mineral aggregates (AMA's) consisting of individual oxides as $\mathrm{Fe}_{2} \mathrm{O}_{3}, \mathrm{Cu}_{2} \mathrm{O}$ y $\mathrm{Ag}_{2} \mathrm{O}$ and combined oxides as $\mathrm{Fe}_{2} \mathrm{O}_{3}-\mathrm{Cu}_{2} \mathrm{O}, \mathrm{Fe}_{2} \mathrm{O}_{3}-\mathrm{Ag}_{2} \mathrm{O}, \mathrm{Cu}_{2} \mathrm{O}-\mathrm{Ag}_{2} \mathrm{O}, \mathrm{Fe}_{2} \mathrm{O}_{3}-\mathrm{Cu}_{2} \mathrm{O}-\mathrm{Ag}_{2} \mathrm{O}$, contained in alginate beads, was compared. The results indicate that $\mathrm{Ag}_{2} \mathrm{O}$ and $\mathrm{Fe}_{2} \mathrm{O}_{3}-\mathrm{Ag}_{2} \mathrm{O}, \mathrm{Cu}_{2} \mathrm{O}-\mathrm{Ag}_{2} \mathrm{O}$ combinations, as well as NMA, inactivated $100 \%$ of $E$. coli in 30 min, whereas the oxides mixture, $\mathrm{Fe}_{2} \mathrm{O}_{3}-\mathrm{Cu}_{2} \mathrm{O}-\mathrm{Ag}_{2} \mathrm{O}$, took $13 \mathrm{~min}$. It was observed that redox potential values were closely related to the disinfection level achieved. The advantage resulting from using alginate beads was that these allow the formation of AMA, which has higher disinfectant ability relative to NMA.
\end{abstract}

Keywords: disinfection, biological effluent, $\mathrm{Fe}_{2} \mathrm{O}_{3}, \mathrm{Cu}_{2} \mathrm{O}$ and $\mathrm{Ag}_{2} \mathrm{O}$, alginate beads, Escherichia coli, natural mineral aggregate, artificial mineral aggregate

\section{Introduction}

Biological effluents from domestic wastewater treatment are required to be disinfected before reuse (Liberti et al., 2000) because they still contain microorganisms of intestinal origin, such as helminth ova and faecal coliform bacteria. Escherichia coli is a bacterium of enteric origin whose occurrence and abundance allows for its use in defining the sanitary quality of water and wastewater. The World Health Organization (WHO, 1989) has established a maximum level of 1000 faecal coliforms unit (FCU)/100 $\mathrm{m} \ell$ for Category A water quality. Chlorination is the most widely used wastewater disinfection method, even though it has a drawback due to the formation of trihalomethanes and organochlorinated compounds which are carcinogens. An alternative disinfection method is the use of some metals, either alone or combined, such as $\mathrm{Fe}, \mathrm{Cu}$ or $\mathrm{Ag}$ in the solid state (Davies and Etris, 1997; You et al., 2005), in ionic form (Craig, 2001; Jiang et al., 2006a; Silva-Martínez et al., 2004; Silvestry-Rodriguez et al., 2007), in combination with UV light (Kim et al., 2008) or as formulations where metal ions of $\mathrm{Al}, \mathrm{Cu}$ or $\mathrm{Ag}$ are added to a solid matrix like zeolites (Rivera-Garza et al., 2000; De La Rosa-Gómez et al., 2008), ceramic material (Kim et al., 2004), silicates (Kawashita et al., 2003), colloids and metal nanoparticles (Chaloupka et al., 2010; Cho et al., 2005; Choi et al., 2008; Li et al., 2008), polymers (Lukhele et al., 2010) or biopolymers (Yi et al., 2003). However, experiences in using metals for disinfecting wastewater have been few, and mainly consist of using metal ions in combination with other chemical disinfectants, such as chlorine, hydrogen peroxide or peracetic acid (PAA). These combinations of disinfectants have been applied to influents from advanced primary treatment (APT), biological effluents or raw water (Pedahzur et al., 1995; Orta de Velásquez et al., 2008; Luna-Pabello et al., 2009). In most cases, for achieving

\footnotetext{
* To whom all correspondence should be addressed.

푠 + (52) 562237 63; fax: + (52) 562237 63;

e-mail: victormlp@yahoo.com

Received 16 January 2010; accepted in revised form 1 February 2011.
}

total inactivation of test microorganisms, contact time tends to be large, i.e. up to $2 \mathrm{~h}$ (Table 1).

Mineral aggregates present an opportunity for improvement. Mineral aggregates may contain metals such as $\mathrm{Fe}, \mathrm{Cu}$ and $\mathrm{Ag}$ at their different oxidation states, thus increasing their germicidal effect. These metals contribute to inhibition of the cellular respiration process, due to the inactivation of - $\mathrm{SH}$ radicals of respiration enzymes, the interruption of the electrontransfer chain and DNA and RNA disruption (Davies and Etris, 1997; Silva-Martínez et al., 2004; Holt and Bard, 2005; Sharma et al., 2005; Yamanaka et al., 2005; Silvestry-Rodriguez et al., 2007; Park et al., 2009; Chaloupka et al., 2010). Natural mineral aggregates (NMAs) have shown germicidal activity but they exhibit drawbacks such as not having a homogeneous composition and containing undesirable metals such as $\mathrm{As}$ and $\mathrm{Pb}$ (Miranda-Ríos and Luna-Pabello, 2002-2003).

A possible matrix to make artificial mineral aggregates is sodium alginate, which is a natural ionic polysaccharide having many applications in the food and pharmaceutical industries (Braccini and Pérez, 2001). Alginate has been used for immobilising biomolecules and also is a strong chelating agent for metals. With most divalent cations, it produces gels that are heat irreversible (Park et al., 2007).

Based on the above, the objective of this study was to determine the contact time required to disinfect a biological effluent containing $E$. coli, at initial concentrations of $10^{5} \mathrm{CFU} /$ $\mathrm{m} \ell$, using silver shot, copper shot, natural mineral aggregates (NMA's) and artificial mineral aggregates (AMA's) formed with $\mathrm{Fe}_{2} \mathrm{O}_{3} \mathrm{Cu}_{2} \mathrm{O}, \mathrm{Ag}_{2} \mathrm{O}$, separated or combined.

\section{Experimental}

Sterile biological effluent: The biological effluent was obtained from Ciudad Universitaria UNAM, located at the southern zone of Mexico City. Two hundred litres were collected from the effluent of the activated sludge system, before it passes through the sand filter, and was subjected to physicochemical analysis as described by Eaton et al. (2005), and then sterilised by autoclaving at $1.1 \mathrm{~kg} / \mathrm{cm}^{2}, 120^{\circ} \mathrm{C}$ for $15 \mathrm{~min}$. 


\begin{tabular}{|c|c|c|c|c|}
\hline \multicolumn{5}{|c|}{$\begin{array}{c}\text { Table } 1 \\
\text { Water and wastewater test disinfection using metals }\end{array}$} \\
\hline $\begin{array}{l}\text { Disinfectant/ } \\
\text { Concentration }\end{array}$ & Test water & $\begin{array}{l}\text { Test microorganism/ } \\
\text { Concentration }\end{array}$ & $\begin{array}{l}\text { Contact timel } \\
\text { Inactivation }\end{array}$ & Reference \\
\hline $\begin{array}{l}\text { Zerovalent Fe in granules } \\
\text { or shot } \\
1.0 \mathrm{~g}\end{array}$ & $\begin{array}{l}\text { Artificial } \\
\text { groundwater }\end{array}$ & $\begin{array}{l}\text { Bacteriophages: } \\
\text { 1) } F \mathrm{X} 174 \\
\text { 2) } \mathrm{MS}-2 \\
1 \times 10^{5} \text { plaque-forming unit } / \mathrm{m} \ell\end{array}$ & $\begin{array}{l}120 \mathrm{~min} \\
\text { 1) } 79.41 \%, 0.7 \log _{10} \\
\text { 2) } 94.94 \%, 1.3 \log _{10}\end{array}$ & $\begin{array}{l}\text { You et al., } \\
2005\end{array}$ \\
\hline $\begin{array}{l}\text { Zerovalent } \mathrm{Ag} \text { in granules } \\
\text { or shot } \\
1.0 \mathrm{~g}\end{array}$ & $\begin{array}{l}\text { Sterile biologi- } \\
\text { cal secondary } \\
\text { effluent }\end{array}$ & $\begin{array}{l}\text { Escherichia coli ATCC 25922, } \\
7.4 \times 10^{5} \mathrm{CFU} / 100 \mathrm{~m} \ell\end{array}$ & $\begin{array}{l}90 \mathrm{~min}, \\
100 \%, 3 \log _{10}\end{array}$ & $\begin{array}{l}\text { Miranda- } \\
\text { Ríos and } \\
\text { Luna-Pabello, } \\
\text { 2002-2003 }\end{array}$ \\
\hline $\begin{array}{l}\mathrm{K}_{2} \mathrm{FeO}_{4} \\
\mathrm{Fe}(\mathrm{VI}) \\
\text { 1) } 6.0 \mathrm{mg} / \ell \\
\text { 2) a. } 6.0 \mathrm{mg} / \ell \\
\text { b. } 15.0 \mathrm{mg} / \ell\end{array}$ & $\begin{array}{l}\text { 1) Sterile phos- } \\
\text { phate buffered } \\
\text { water } \\
\text { 2) Secondary } \\
\text { sewage effluent }\end{array}$ & $\begin{array}{l}\text { f2 virus } \\
1 \times 10^{5}-1 \times 10^{7} \text { cells } / \mathrm{m} \ell\end{array}$ & $\begin{array}{l}\text { 1) } 1 \mathrm{~min}, 99 \% \mathrm{f} 2 \text { virus } \\
\text { 2) a. } 13 \mathrm{~min}, 99 \% \text { for } \mathrm{f} 2 \text { virus } \\
\text { b. } 60 \mathrm{~min}, 99 \% \text { for bacteria, } \\
1 \mathrm{~min}, 100 \% \text { for } \mathrm{f} 2 \text { virus }\end{array}$ & $\begin{array}{l}\text { Schink and } \\
\text { Waite, } 1980\end{array}$ \\
\hline $\begin{array}{l}\mathrm{K}_{2} \mathrm{FeO}_{4} \\
\mathrm{Fe}(\mathrm{VI}) \\
\text { 1) } 6.0 \mathrm{mg} / \ell \\
\text { 2) } 15.0 \mathrm{mg} / \ell\end{array}$ & $\begin{array}{l}\text { 1) Tap water } \\
\text { 2) Raw } \\
\text { wastewater }\end{array}$ & $\begin{array}{l}\text { 1) E. coli } 3.2 \times 10^{8} \text { CFU/ } 100 \\
\text { m } \ell \\
\text { 2) Faecal coliforms } 3.3 \times 10^{8}- \\
2 \times 10^{9} \mathrm{FCU} / 100 \mathrm{~m} \ell\end{array}$ & $\begin{array}{l}\text { 1) } 30 \mathrm{~min}, 100 \%, 8 \log _{10} \\
\text { 2) } 80 \mathrm{~min}, 99.99 \%,>4 \log _{10}\end{array}$ & $\begin{array}{l}\text { Jiang et al., } \\
2006 a ; b ; \\
2007\end{array}$ \\
\hline $\begin{array}{l}\text { Electrolytic } \mathrm{Cu} \text { and } \mathrm{Ag} \text { ions } \\
\text { 1) } 1.2 \mathrm{mg} / \ell \mathrm{Cu} / 0.6 \mathrm{mg} / \ell \mathrm{Ag} \\
\text { 2) } 0.6 \mathrm{mg} / \ell \mathrm{Cu} / 1.2 \mathrm{mg} / \ell \mathrm{Ag} \\
\text { 3) } 1.2 \mathrm{mg} / \ell \mathrm{Cu} / 0.2 \mathrm{mg} / \ell \mathrm{Ag} / \\
0.3 \mathrm{mg} / \ell \mathrm{Cl}_{2}\end{array}$ & $\begin{array}{l}\text { 1) Biological } \\
\text { secondary } \\
\text { effluent } \\
\text { 2) Cooling } \\
\text { water }\end{array}$ & $\begin{array}{l}\text { 1) Total coliforms and } E . \text { coli, } \\
2.5 \times 10^{8} \mathrm{MPN} / 100 \mathrm{~m} \ell \\
\text { 2) Total coliforms, } 5.0 \times 10^{8} \\
\text { MPN/100 m } \ell \text { and } E . \text { coli, } \\
2.0 \times 10^{8} \mathrm{MPN} / 100 \mathrm{~m} \ell\end{array}$ & $\begin{array}{l}\text { 1) } 2.0 \mathrm{~h} \text {, total elimination of } \\
\text { coliforms and } E \text {. coli } \\
\text { 2) } 2.0 \mathrm{~h} \text {, total elimination of } \\
\text { coliforms and } E \text {. coli }\end{array}$ & $\begin{array}{l}\text { Silva- } \\
\text { Martínez et } \\
\text { al., } 2004\end{array}$ \\
\hline $\begin{array}{l}\mathrm{Cu}, \mathrm{Ag} \text { ions and } \mathrm{Cl}_{2} \\
\text { 1) } 0.8 \mathrm{mg} / \ell \mathrm{Cu}, 0.08 \mathrm{mg} / \ell \mathrm{Ag} \\
\text { 2) } 0.8 \mathrm{mg} / \ell \mathrm{Cu} / 0.08 \mathrm{mg} / \ell \\
\mathrm{Ag} / 1.00 \mathrm{mg} / \ell \mathrm{Cl}\end{array}$ & Well water & $\begin{array}{l}\text { Naeglaeria fowleri ATCC } \\
30894, \\
1 \times 10^{4} \text { viable amoebas } / \mathrm{m} \ell\end{array}$ & $\begin{array}{l}\text { 1) } 72 \mathrm{~h}, 14.5 \%\left(0.58 \log _{10}\right) \\
\text { 2) } 3.9 \mathrm{~min}, 99 \%\end{array}$ & $\begin{array}{l}\text { Cassells et } \\
\text { al., } 1995\end{array}$ \\
\hline $\begin{array}{l}\mathrm{Ag}, \mathrm{Cu} \\
\text { 1) } 100+1000 \mu \mathrm{g} / \mathrm{\ell} \\
\text { 2) } 500+5000 \mu \mathrm{g} / \ell\end{array}$ & In vitro & $\begin{array}{l}\text { Hartmannella vermiformis } \\
\text { amoebas and the ciliated proto- } \\
\text { zoan Tetrahymena pyriformis }\end{array}$ & $\begin{array}{l}\text { 1)Tetrahymena and } \\
\text { Hartmannella, } 2 \text { log reduction } \\
\text { 2) Hartmannella, } 0.6 \mathrm{log} \\
\text { reduction. }\end{array}$ & $\begin{array}{l}\text { Rohr et al., } \\
2000\end{array}$ \\
\hline $\begin{array}{l}\mathrm{Fe}(+3) \text { or } \mathrm{Cu}(+2) \text { in zeolite } \\
(27.5 \text { and } 2.0 \mathrm{mg} / \mathrm{g})\end{array}$ & $\begin{array}{l}\text { Municipal sew- } \\
\text { age treatment } \\
\text { plant }\end{array}$ & 1) Faecal coliforms & 1) $2 \log$ reduction in $6 \mathrm{~h}$ & $\begin{array}{l}\text { Milan et al., } \\
2001\end{array}$ \\
\hline $\begin{array}{l}\text { Ag zeolite } \\
(14 \% \mathrm{w} / \mathrm{w})\end{array}$ & Residual efluent & $10^{6} \mathrm{FCU} / 100 \mathrm{m \ell}$ & $\begin{array}{l}110-129 \min , \\
\text { Category A }\end{array}$ & $\begin{array}{l}\text { De la Rosa- } \\
\text { Gómez et al., } \\
2008\end{array}$ \\
\hline $\begin{array}{l}\text { 1) } \mathrm{AgNO}_{3}(1.0 \mathrm{mg} / \mathrm{\ell}) \\
\text { 2) } \mathrm{Ag} \text { ions and } \mathrm{UV}-\mathrm{A} \\
(54 \mathrm{~mW} / \mathrm{cm} 2,300-400 \mathrm{~nm}) \\
\text { 3) } \mathrm{Ag} \text { ions and visible light } \\
\text { irradiation } \\
(93 \mathrm{~mW} / \mathrm{cm} 2,400-700 \mathrm{~nm})\end{array}$ & $\begin{array}{l}\text { Phosphate } \\
\text { buffer } \mathrm{pH}=7\end{array}$ & $\begin{array}{l}\text { E. coli } \text { and MS- } 2 \text { phage } 1 \times 10^{5}- \\
2 \times 10^{5} \mathrm{CFU} \text { or PFU/m } \ell\end{array}$ & $\begin{array}{l}\text { 1) } 30 \mathrm{~min}, 1.5 \log \text { E. coli } \text { and } \\
\text { 2.5 log MS-2 phage } \\
\text { 2) } 30 \mathrm{~min}, 4.5 \log E \text {. coli and } 5.0 \\
\log \mathrm{MS}-2 \text { phage } \\
\text { 3) } 30 \mathrm{~min}, 2.0 \log \text { E. coli } \text { and } 4.5 \\
\log \mathrm{MS}-2 \text { phage }\end{array}$ & $\begin{array}{l}\text { Kim et al., } \\
2008\end{array}$ \\
\hline $\begin{array}{l}\text { 1) Colloidal Ag nanoparticles } \\
\text { (20 } \mu \mathrm{g} / \mathrm{g} \text { and } 10 \mu \mathrm{g} / \mathrm{g}) \\
\text { 2) Colloidal Pt nanoparticles } \\
(20 \mu \mathrm{g} / \mathrm{g} \text { and } 10 \mu \mathrm{g} / \mathrm{g})\end{array}$ & \begin{tabular}{|l|} 
LB medium \\
diluted in $\mathrm{NaCl}$ \\
$(0.85 \%)$
\end{tabular} & $\begin{array}{l}\text { a) Staphylococcus aureus } \\
\text { b) E. coli } \\
10^{5}-10^{6} \mathrm{CFU} / \mathrm{m} \ell\end{array}$ & $\begin{array}{l}\text { 1) a. } 3.3-4 \mathrm{~h} \text { total elimination } \\
\text { b. } 2.5 \text { to } 3.5 \mathrm{~h} \text {. total } \\
\text { elimination } \\
\text { 2) No elimination }\end{array}$ & $\begin{array}{l}\text { Cho et al., } \\
2005\end{array}$ \\
\hline $\begin{array}{l}\text { 1) } \mathrm{Ag} \text { nanoparticles } \\
\text { 2) } \mathrm{Silver} \text { ions }(\mathrm{AgCl}) \\
\text { 3) } \mathrm{AgCl} \text { colloidal } \\
\text { 1.4 } \mu \mathrm{M} \\
2.8 \mu \mathrm{M} \\
4.2 \mu \mathrm{M}\end{array}$ & BBL broth & $\begin{array}{l}\text { E. coli } \text { PHL628-gfp } \\
\text { (No data) }\end{array}$ & $\begin{array}{l}\text { At } 5 \text { hours } \\
\text { 1) a. } 17.0 \% \\
\text { b. } 30.0 \% \\
\text { c. } 55.0 \% \\
\text { 2) a. } 11.0 \% \\
\text { b. } 69.0 \% \\
\text { c. } 100.0 \% \\
\text { 3) a. } 7.0 \% \\
\text { b. } 24.0 \% \\
\text { c. } 66.0 \%\end{array}$ & $\begin{array}{l}\text { Choi et al., } \\
2008\end{array}$ \\
\hline
\end{tabular}




\begin{tabular}{|c|c|c|c|c|}
\hline $\begin{array}{l}\text { Silver nanoparticles in poly- } \\
\text { meric microspheres, } \\
100 \mathrm{mg}\end{array}$ & $\begin{array}{l}\text { Autoclaved } \\
\text { water }\end{array}$ & $\begin{array}{l}\text { E. coli ATCC } 8739\left(7 \times 10^{6}\right. \\
\text { CFU/m } \ell) \\
\text { P. aeruginosa ATCC } 9027 \\
\left(22 \times 10^{6} \text { CFU } / \mathrm{m} \ell\right) \\
\text { B. subtilis ATCC } 6051\left(46 \times 10^{6}\right. \\
\text { CFU } / \mathrm{m} \ell) \\
\text { S. aureus ATCC } 25923\left(24 \times 10^{6}\right. \\
\text { CFU } / \mathrm{m} \ell)\end{array}$ & $\begin{array}{l}\text { At } 2 \mathrm{~h} \\
2.64 \log \\
3.87 \mathrm{log} \\
4.06 \log \\
2.65 \mathrm{log}\end{array}$ & $\begin{array}{l}\text { Gangadharan } \\
\text { et al., } 2010\end{array}$ \\
\hline $\begin{array}{l}\text { Silver } \\
\left(\text { AgNO }_{3} 0.01 \mathrm{M}\right) \\
\text { carbon nanotubes polymer- } \\
\text { ised with } \beta \text { cyclodextrin } \\
\text { Carbon nanotubes polymer- } \\
\text { ized with } \beta \text { cyclodextrin } \\
\text { Polyurethane with } \beta \\
\text { cyclodextrin }\end{array}$ & $\begin{array}{l}\text { Sterile distilled } \\
\text { water }\end{array}$ & $\begin{array}{l}\text { E.coli }(\text { ATCC25925) } \\
\left(1.3 \times 10^{7} \mathrm{CFU} / \mathrm{m} \ell\right)\end{array}$ & $\begin{array}{l}30 \mathrm{~min}, 94 \% \\
60 \mathrm{~min}, 95 \% \\
90 \mathrm{~min}, 100 \% \\
30 \mathrm{~min}, 84 \% \\
60 \mathrm{~min}, 48 \% \\
90 \mathrm{~min}, 45 \% \\
30 \mathrm{~min}, 72 \% \\
60 \mathrm{~min}, 70 \% \\
90 \mathrm{~min}, 48 \%\end{array}$ & $\begin{array}{l}\text { Lukhele et } \\
\text { al., } 2010\end{array}$ \\
\hline $\begin{array}{l}\text { 1) PAA and } \mathrm{Ag} \\
\text { (7.5-1.0 mg/l) } \\
\text { 2) } \mathrm{H}_{2} \mathrm{O}_{2} \text { and } \mathrm{Ag} \\
(200-1.0 \mathrm{mg} / \mathrm{l}) \\
\text { 3) } \mathrm{H}_{2} \mathrm{O}_{2}, \mathrm{Cu} \\
(50-1.0 \mathrm{mg} / \mathrm{l})\end{array}$ & APT effluent & $10^{6} \mathrm{FCU} / 100 \mathrm{m \ell}$ & $\begin{array}{l}\text { 1) } 45 \text { min Category A } \\
\text { 2) } 30 \text { min Category A } \\
\text { 3) } 30 \text { min Category A; } 120 \mathrm{~min} \\
\text { total elimination }\end{array}$ & $\begin{array}{l}\text { Orta de } \\
\text { Velásquez et } \\
\text { al., } 2008\end{array}$ \\
\hline $\begin{array}{l}\text { PAA, Cu, Ag } \\
(20.0-0.1-1.0 \mathrm{mg} / \ell)\end{array}$ & $\begin{array}{l}\text { Biological } \\
\text { effluent }\end{array}$ & $10^{5} \mathrm{FCU} / 100 \mathrm{m \ell} \mathrm{CF}$ & 10 min Category $\mathrm{A}$ & \begin{tabular}{|l|}
$\begin{array}{l}\text { Luna-Pabello } \\
\text { et al., } 2009\end{array}$ \\
\end{tabular} \\
\hline $\begin{array}{l}\text { Colloidal silver } \\
(0.5 \mathrm{mg} / \ell)\end{array}$ & $\begin{array}{l}\text { Sterilised bio- } \\
\text { logical efluent }\end{array}$ & $10^{6} \mathrm{CFU} / 100 \mathrm{m \ell}$ E. coli & 15 min total elimination & $\begin{array}{l}\text { Miranda- } \\
\text { Ríos and } \\
\text { Luna-Pabello, } \\
\text { 2002-2003 }\end{array}$ \\
\hline
\end{tabular}

Inoculum: Escherichia coli ATCC 25922 bacteria preserved on nutritive agar (BBL) were inoculated in an Erlenmeyer flask containing $100.0 \mathrm{~m} \ell$ of sterile nutritive broth (BBL) and were placed overnight in an incubator with orbital agitation (G24 New Brunswick) at $37^{\circ} \mathrm{C}$ and $250.0 \mathrm{r} / \mathrm{min}$. After $18 \mathrm{~h}$ of incubation the inoculum was adjusted with nutritive broth at OD of 1.4 at $600 \mathrm{~nm}$ wavelength using an UV-VIS spectrophotometer (Pharmacia Biotech, Ultrospec 3000). Subsequently, $10.0 \mathrm{~m} \ell$ of inoculum were diluted in $99.0 \mathrm{m \ell}$ of sterile distilled water. One millilitre from this decimal dilution was pre-adapted in a flask containing $99.0 \mathrm{~m} \ell$ of the sterile biological effluent. The flask was again placed in the incubator with orbital agitation for $24 \mathrm{~h}$.

Escherichia coli presence is the most reliable indicator of faecal bacterial contamination of surface waters in different countries. An appropriate health-based indicator of microbial pathogens should possess several characteristics (Arana et al., 2000). The indicator should always be present when pathogens are present and should not be detected when the pathogens are absent; it should have a life span similar to that of the pathogens of concern; it should be present in large numbers and should be readily detected by simple and inexpensive methods; and it should not multiply in the environment once it has been shed by the host. Based on these conditions, if the indicator is isolated from the water under examination the pathogenic organisms could still be present; if the indicator is absent, pathogenic organisms are also probably absent (Eaton et al., 2005; Kim et al., 2008).

Water for testing: Water for testing was prepared by adding $5.0 \mathrm{~m} \ell$ of pre-adapted $E$. coli at a concentration of $10^{6} \mathrm{CFU} /$ $\mathrm{m} \ell$ for each $95.0 \mathrm{~m} \ell$ of sterile biological effluent, to obtain a concentration of $10^{5} \mathrm{CFU} / \mathrm{m} \ell$.
Preparation of alginate beads: Sodium alginate solution was prepared dissolving $7.5 \mathrm{~g}$ of sodium alginate (Sigma), 3500 $\mathrm{mPa} \cdot \mathrm{s}$ and $2.5 \mathrm{~g}$ sodium alginate (Sigma), $14000 \mathrm{mPa} \cdot \mathrm{s}$, in 400 $\mathrm{m} \ell$ of distilled water. This solution was sterilised by autoclaving, was allowed to cool and then powdered $\mathrm{Fe}_{2} \mathrm{O}_{3}, \mathrm{Cu}_{2} \mathrm{O}$ (J.T. Baker) and $\mathrm{Ag}_{2} \mathrm{O}$ (Merck) were added to it. The solution was homogenised with a magnetic agitator until it was completely dissolved. The addition of each oxide was calculated for obtaining the same percentage by weight as that of NMA (see Table 2). The above mixture was taken by a $3.0 \mathrm{~m} \ell$ sterile syringe and then was added drop by drop to a $2.0 \%$ calcium chloride solution (J.T. Baker), thus forming alginate beads which contain metals. These beads, which have a diameter of $2.00 \mathrm{~mm}$, are filtered off from the $\mathrm{CaCl}_{2}$ solution and are allowed to dry. As a blank, alginate beads with no added metals were prepared.

\begin{tabular}{|c|c|c|c|c|}
\hline \multicolumn{5}{|c|}{$\begin{array}{c}\text { Table } 2 \\
\text { Metal oxides content in beads formed } \\
\text { with sodium alginate }\end{array}$} \\
\hline \multirow{2}{*}{$\begin{array}{l}\text { Oxide in the } \\
\text { alginate beads }\end{array}$} & \multirow{2}{*}{$\begin{array}{l}\text { Sodium } \\
\text { alginate }(g)\end{array}$} & \multicolumn{3}{|c|}{ Metals (g) } \\
\hline & & $\mathrm{Fe}_{2} \mathrm{O}_{3}$ & $\mathrm{Cu}_{2} \mathrm{O}$ & $\mathrm{Ag}_{2} \mathrm{O}$ \\
\hline $\mathrm{Fe}_{2} \mathrm{O}_{3}$ & 97.46 & 2.5449 & - & - \\
\hline $\mathrm{Cu}_{2} \mathrm{O}$ & 99.99 & - & 0.0116 & - \\
\hline $\mathrm{Ag}_{2} \mathrm{O}$ & 99.99 & - & - & 0.0109 \\
\hline $\mathrm{Fe}_{2} \mathrm{O}_{3}-\mathrm{Cu}_{2} \mathrm{O}$ & 99.44 & 2.5449 & 0.0116 & - \\
\hline $\mathrm{Fe}_{2} \mathrm{O}_{3}-\mathrm{Ag}_{2} \mathrm{O}$ & 99.44 & 2.5449 & - & 0.0109 \\
\hline $\mathrm{Cu}_{2} \mathrm{O}-\mathrm{Ag}_{2} \mathrm{O}$ & 99.98 & - & 0.0116 & 0.0109 \\
\hline $\mathrm{Fe}_{2} \mathrm{O}_{3}-\mathrm{Cu}_{2} \mathrm{O}-\mathrm{Ag}_{2} \mathrm{O}$ & 97.43 & 2.5449 & 0.0116 & 0.0109 \\
\hline
\end{tabular}

Microbiological analysis: The concentration of E. coli was determined by the dilutions method and by the technique of membrane filter using sterile nitrocellulose filters (Millipore, 
Bedford, MA, USA) with a pore size of $0.45 \mu \mathrm{m}$ and a diameter of $47 \mathrm{~mm}$ and agar M-FC (BBL) added with rosolic acid (Hycel de México, S.A. de C.V.) at $2 \%$ in $\mathrm{NaOH}$ (Merck) (Eaton et al., 2005). Petri dishes were placed in a water jacketed incubator (Ac-Lab) for $24 \mathrm{~h}$ at a temperature of $44.5^{\circ} \mathrm{C}$.

Physicochemical characterisation of

NMA: A natural mineral aggregate (NMA) with a particle size ranging between 2.0 to $3.36 \mathrm{~nm}$, was obtained from a mine located in Zacatecas State, Mexico. This material was characterised by X-ray diffraction techniques and inductively-coupled plasma atomic emission spectroscopy (ICP-OES) (Eaton et al., 2005).

Disinfection tests: To evaluate disinfecting capacity of NMA and alginate beads containing separate oxides, 4 tests were carried out:

- NMA

- Alginate beads containing separate oxides

- Oxide pairs: $\mathrm{Fe}_{2} \mathrm{O}_{3}-\mathrm{Cu}_{2} \mathrm{O}, \mathrm{Fe}_{2} \mathrm{O}_{3}-\mathrm{Ag}_{2} \mathrm{O}$ and $\mathrm{Cu}_{2} \mathrm{O}-\mathrm{Ag}_{2} \mathrm{O}$

- Triple combination $\mathrm{Fe}_{2} \mathrm{O}_{3}-\mathrm{Cu}_{2} \mathrm{O}-\mathrm{Ag}_{2} \mathrm{O}$

From each flask, $100.0 \mathrm{~m} \ell$ of water for testing was taken, and for each test either $1 \mathrm{~g}$ of NMA or $1 \mathrm{~g}$ of alginate beads was added, as shown in Table 3. Flasks were placed in an incubator with orbital agitation, at $37^{\circ} \mathrm{C}$ and $250 \mathrm{r} / \mathrm{min}$. At pre-established contact times of $0.0,30.0$ and $60.0 \mathrm{~min}$ or $0,15.0$ and $30.0 \mathrm{~min}$, the concentration of surviving bacteria was determined, as well as $\mathrm{pH}$, dissolved $\mathrm{O}_{2}$ and redox potential. The disinfectant activity of alginate beads containing metal oxides and NMA was stopped by adding a neutralising solution prepared with 280.0 $\mathrm{m} \ell$ of Tween 80 (Sigma), $40.0 \mathrm{~g}$ of soy lecithin and $1.25 \mathrm{~m} \ell$ of phosphate buffer solution, making the volume up to $1 \ell$ with distilled water. Once homogenised, the solution was sterilised by autoclaving at $1.1 \mathrm{~kg} / \mathrm{cm}^{2}, 120^{\circ} \mathrm{C}$ for $15 \mathrm{~min}$ (Bloomfield, 1991). This neutralising solution was used either applying $1.0 \mathrm{~m} \ell$ on the membrane, where direct seeding is carried out, or in amounts of $9.0 \mathrm{~m} \ell$ applied into the assay tubes used for preparing the $10^{-1}$ decimal dilution, for seeding by diluting. The experiments were conducted in triplicate and the results presented are mean values. The results were analysed statistically using SPSS 15.0 software. Statistical analysis consisting of a factorial analysis of variance (ANOVA) was performed on the entire data set to determine if significant differences existed between the results obtained using different types of disinfectant (NMA or AMA) and contact time. The differences between treatments were analysed by Tukey's HSD (Honestly Significantly Different) test at $P<0.05$.

Kinetics of disinfection - The kinetics of disinfection was established according to the Hom equation (Gyürék and Finch, 1998). In this model, the concentration of disinfectant remains unchanged during the disinfection process.

$$
N_{t} / N_{0}=\exp \left(-k^{*} t^{m}\right)
$$

where:

$t=$ time (minutes)

$\mathrm{Nt} / \mathrm{NO}=$ quantity of surviving microorganisms,

$\mathrm{k}^{*}=$ Constant, time -1 , this constant includes the die-off coefficient and the disinfectant doses $\mathrm{C}^{\mathrm{n}}$ (when $n=1$ ) and $m$ without change.
Table 3

Experimental conditions for disinfection test

\begin{tabular}{l} 
Contact time (min) \\
$0,15,30,60$ \\
$0,15,30,60$ \\
\hline $0,15,30$ \\
\hline $0,5,10,15$ and $0,15,30$ \\
\hline
\end{tabular}

\begin{tabular}{|c|c|c|c|}
\hline \multicolumn{4}{|c|}{$\begin{array}{c}\text { Table } 4 \\
\text { Microbiological and physicochemical } \\
\text { characteristics of the biological effluent } \\
\text { before it was subjected to sterilisation }\end{array}$} \\
\hline \multicolumn{2}{|c|}{ Parámeter } & \multicolumn{2}{|c|}{ Parámeter } \\
\hline $\mathrm{pH}\left(25^{\circ} \mathrm{C}\right)$ & 7.7 & Arsenic $(\mathrm{mg} / \mathrm{l})$ & 0.0007 \\
\hline $\mathrm{BOD}_{5}(\mathrm{mg} / \mathrm{l})$ & 32 & Cadmium (mg/l) & $<0.005$ \\
\hline $\mathrm{COD}(\mathrm{mg} / \ell)$ & 99 & Cyanides $(\mathrm{mg} / \ell)$ & $<0.02$ \\
\hline TDS (mg/l) & 18 & Copper $(\mathrm{mg} / \mathrm{l})$ & 0.01 \\
\hline $\mathrm{SS}(\mathrm{m} \ell / \ell)$ & $<0.1$ & Chromium (mg/l) & $<0.02$ \\
\hline $\begin{array}{l}\text { Nitrates } \\
(\mathrm{mg} / \ell)\end{array}$ & 1.86 & Mercury $(\mathrm{mg} / \mathrm{l})$ & 0.0015 \\
\hline Nitrites $(\mathrm{mg} / \mathrm{l})$ & 0.097 & Nickel (mg/l) & $<0.025$ \\
\hline $\begin{array}{l}\text { Kjeldahl } \\
\text { Nitrogen } \\
(\mathrm{mg} / \mathrm{l})\end{array}$ & 22.85 & Silver (mg/l) & $<0.01$ \\
\hline $\begin{array}{l}\text { Total nitrogen } \\
(\mathrm{mg} / \mathrm{\ell})\end{array}$ & 24.807 & Lead $(\mathrm{mg} / \ell)$ & $<0.025$ \\
\hline $\begin{array}{l}\text { Total phos- } \\
\text { phorus (mg/l) }\end{array}$ & 4.14 & Zinc (mg/l) & $<0.01$ \\
\hline $\begin{array}{l}\text { Oil and } \\
\text { greases }(\mathrm{mg} / \ell)\end{array}$ & $<5$ & & \\
\hline $\begin{array}{l}\text { Faecal coli- } \\
\text { forms (FCU/ } \\
\mathrm{m} \ell)\end{array}$ & $8.6 \times 10^{3}$ & $\begin{array}{l}\text { Helminth ova } \\
(\mathrm{HE} / \ell)\end{array}$ & $4-5$ \\
\hline
\end{tabular}

\section{Results and discussion}

The results of microbiological and physicochemical characterisation of the effluent of the activated sludge system before it was sterilised, are shown in Table 4. The data indicate that it corresponds to a typical secondary effluent (Metcalf and Eddy, 2004; Orta de Velásquez et al., 2008; Luna-Pabello et al., 2009).

The results of physicochemical characterisation of NMA by the $\mathrm{x}$-ray diffraction technique indicate that is comprised of quartz, sanidine, nymite, montmorillonite, calcite and $\mathrm{Fe}$ oxide (III). ICP-OES analysis indicated that NMA contains Fe $(1.78 \% \mathrm{w} / \mathrm{w})$ in a higher proportion than other metals, such as $\mathrm{Cu}(0.0103 \% \mathrm{w} / \mathrm{w}), \mathrm{Zn}(0.0743 \% \mathrm{w} / \mathrm{w}), \mathrm{As}(0.0037 \% \mathrm{w} / \mathrm{w}), \mathrm{Ag}$ $(0.0101 \% \mathrm{w} / \mathrm{w})$ and $\mathrm{Pb}(0.0448 \% \mathrm{w} / \mathrm{w})$. Despite the concentrations of $\mathrm{As}$ and $\mathrm{Pb}$ being detected in low proportions, it is desirable that they would not be present in a disinfected effluent.

$\mathrm{X}$-ray analysis of the bulk flotation product indicated that pyrite $\left(\mathrm{FeS}_{2}\right)$ is the main form of $\mathrm{Fe}$ and indicated the presence of calcite $\left(\mathrm{CaCO}_{3}\right)$ in the NMA. The calcite in the NMA would neutralise any $\mathrm{H}_{2} \mathrm{SO}_{4}$ that might form from a possible pyrite oxidation, freeing carbonate anions. Also, as a result of 


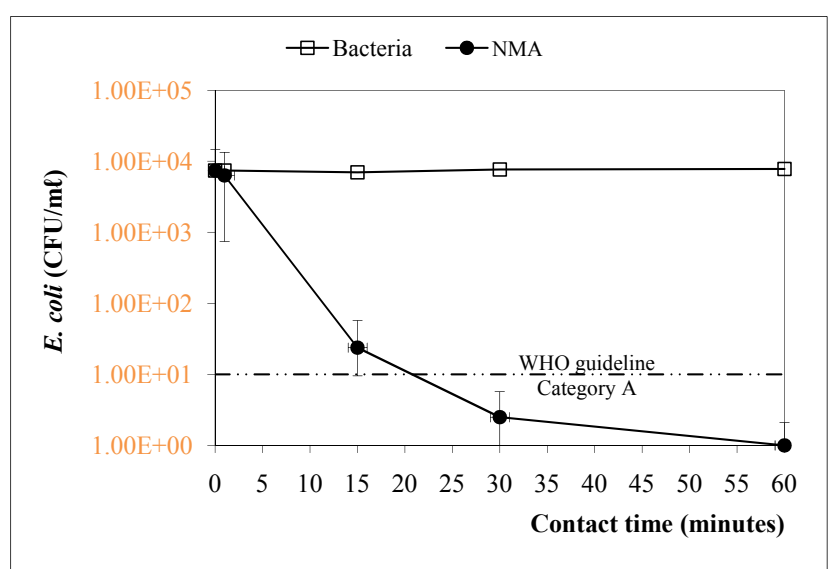

Figure 1

Inactivation of $\mathrm{E}$. coli using NMA

prevalent acidity conditions, soluble $\mathrm{Pb}$ and $\mathrm{As}$ species would form their carbonates and would adsorb onto cemented layers or precipitate on the calcite, and thus reduce the aqueous availability of these metals (Armienta and González Hernández, 2007; Smedley, 2008; Romero et al., 2008; Espinosa et al., 2009).

In the NMA experiments, redox potential in test water was oxidant $(132.6 \pm 0.85 \mathrm{mV})$. Since the $\mathrm{pH}$ values were around $8.5 \pm 0.03$ units, As and $\mathrm{Pb}$ could not be incorporated into the final effluent.. After $30 \mathrm{~min}$ of contact between test water and $\mathrm{NMA}, \mathrm{Fe}, \mathrm{Cu}, \mathrm{As}, \mathrm{Ag}$ and $\mathrm{Pb}$ concentrations were lower than the detection limit in the test water, and $\mathrm{Zn}$ had a concentration of $0.58 \mathrm{mg} / \ell$.

The tests conducted with NMA indicated that almost $100 \%$ of $10^{5} \mathrm{CFU} / \mathrm{m} \ell$ E. coli may be removed during $30 \mathrm{~min}$ of contact (Fig. 1), whereas with copper shot and silver shot 90 min are needed (Miranda-Ríos and Luna-Pabello, 2002-2003). NMA requires from 15 to 30 min to obtain an effluent that would be considered by WHO as Category A, that is, suitable to for reuse in agricultural irrigation (less than $1000 \mathrm{FCU} / 100$ $\mathrm{m} \ell$ ), while a zeolite containing silver at a concentration of $1.4 \%$ $\mathrm{w} / \mathrm{w}$ needs $110 \mathrm{~min}$ to achieve the same disinfection level (De La Rosa-Gómez et al., 2008). Consequently, the combination of metals in NMA exerts a synergistic effect on disinfection because it requires $80 \mathrm{~min}$ less than silver zeolite and $60 \mathrm{~min}$ less than either copper shot or silver shot to achieve the same results. A Tukey HSD test $(P<0.05)$ showed statistically significant differences between the disinfection $\%$ at $15 \mathrm{~min}$ of contact time achieved with use of NMA $(99.679 \%)$ and AMA with $\mathrm{Ag}$ (i.e. $\mathrm{Ag}_{2} \mathrm{O}(99.990 \%), \mathrm{Fe}_{2} \mathrm{O}_{3}-\mathrm{Ag}_{2} \mathrm{O}$ (99.997\%), $\mathrm{Cu}_{2} \mathrm{O}$ $\mathrm{Ag}_{2} \mathrm{O}(99.999 \%)$ and $\mathrm{Fe}_{2} \mathrm{O}_{3}-\mathrm{Cu}_{2} \mathrm{O}-\mathrm{Ag}_{2} \mathrm{O}(100.000 \%)$ alginate beads) versus $\mathrm{AMA}$ without $\mathrm{Ag}$ (i.e. $\mathrm{Fe}_{2} \mathrm{O}_{3}(76.010 \%), \mathrm{Cu}_{2} \mathrm{O}$ $(79.940 \%)$ and $\mathrm{Fe}_{2} \mathrm{O}_{3}-\mathrm{Cu}_{2} \mathrm{O}(49.820 \%)$ alginate beads).

In Fig. 2 and Fig. 3 it can be seen that both alginate beads containing $\mathrm{Ag}_{2} \mathrm{O}$ and those formed with $\mathrm{Fe}_{2} \mathrm{O}_{3}-\mathrm{Ag}_{2} \mathrm{O}$ or $\mathrm{Cu}_{2} \mathrm{O}$ $\mathrm{Ag}_{2} \mathrm{O}$ combinations require less than $30 \mathrm{~min}$ contact time to achieve the total removal of bacteria. In a similar time period, beads with $\mathrm{Fe}_{2} \mathrm{O}_{3}$ and those containing $\mathrm{Cu}_{2} \mathrm{O}$ reduce the initial content of $E$. coli by less than 1 base-10 logarithmic unit $\left(\log _{10}\right)$. Moreover, after a contact time of 15 min, beads with $\mathrm{Fe}_{2} \mathrm{O}_{3}-$ $\mathrm{Cu}_{2} \mathrm{O}$ combination reduce the content of $E$. coli only by 0.32 $\log _{10}$, whereas with beads containing $\mathrm{Fe}_{2} \mathrm{O}_{3}-\mathrm{Ag}_{2} \mathrm{O}$ o $\mathrm{Cu}_{2} \mathrm{O}-\mathrm{Ag}_{2} \mathrm{O}$ the concentration decreases 0.48 and $0.17 \log _{10}$ units, respectively. Finally, for the beads containing $\mathrm{Ag}_{2} \mathrm{O}$, the concentration was reduced to $1.33 \log _{10}$ units, resulting in a survival of more than $1 \log _{10}$.

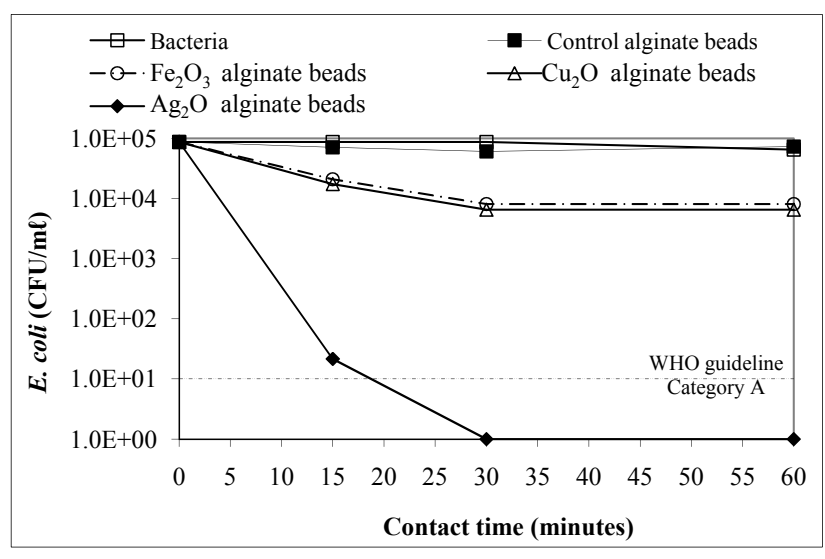

Figure 2

Inactivation of $\mathrm{E}$. coli by alginate beads containing separated metal oxides

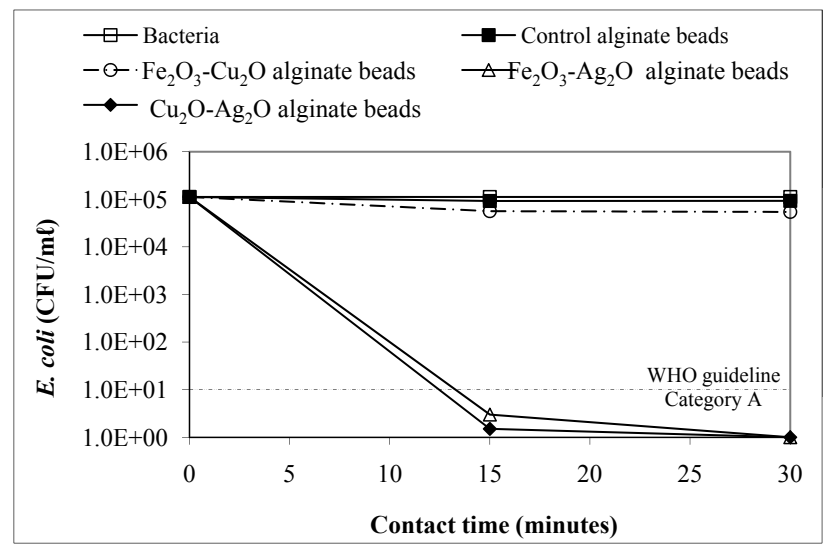

Figure 3

Inactivation of E. coli by alginate beads containing metal oxide pairs

The value corresponding to a Category A effluent is achieved at a contact time from 15 to $30 \mathrm{~min}$ for $\mathrm{Ag}_{2} \mathrm{O}$ beads and from 10 to 15 min for $\mathrm{Fe}_{2} \mathrm{O}_{3}-\mathrm{Ag}_{2} \mathrm{O}$ and $\mathrm{Cu}_{2} \mathrm{O}-\mathrm{Ag}_{2} \mathrm{O}$ beads. As shown in Figs. 2 and 3, the effect produced by the union between $\mathrm{Ag}_{2} \mathrm{O}$ and $\mathrm{Fe}_{2} \mathrm{O}_{3}$ or $\mathrm{Cu}_{2} \mathrm{O}$ is an increase in the disinfecting capacity of silver oxide, requiring a shorter contact time to remove the $E$. coli added, due to the synergistic effect of these oxides on each other. Similar observations for an increase in disinfecting capacity were reported for the union of electrolytically-produced $\mathrm{Cu}$ and $\mathrm{Ag}$ ions (Rohr et al., 2000; Silva-Martínez et al., 2004) or $\mathrm{Cu}$ and $\mathrm{Ag}$ oxides contained in a ceramic matrix (Kim et al., 2004), for water from cooling towers; however, a synergistic effect on disinfection due to $\mathrm{Fe}_{2} \mathrm{O}_{3}$ and $\mathrm{Ag}_{2} \mathrm{O}$ has not been reported.

Figure 4 shows that alginate beads containing the 3 oxides, $\mathrm{Fe}_{2} \mathrm{O}_{3}, \mathrm{Cu}_{2} \mathrm{O}$ and $\mathrm{Ag}_{2} \mathrm{O}$, require a contact time of $13 \mathrm{~min}$ to completely remove $E$. coli, and from 5 to $10 \mathrm{~min}$ to reach the values established by WHO for a Category A effluent. The increase in removal of $E$. coli is again attributed to the synergism of the 3 metals. As observed in Fig. 3, the disinfecting capacity of the $\mathrm{Fe}_{2} \mathrm{O}_{3}-\mathrm{Cu}_{2} \mathrm{O}$ combination is minimal; therefore the increase in the disinfecting capacity with the combination of the 3 oxides is not only attributable to the metals involved, but to the presence of oxygen in the medium. In this sense, an increase in bacterial inactivation has been demonstrated by the production of oxygen-reactive species by silver (Davies and Etris, 1997), both in the matrix containing it (Inoue et al., 2002) 


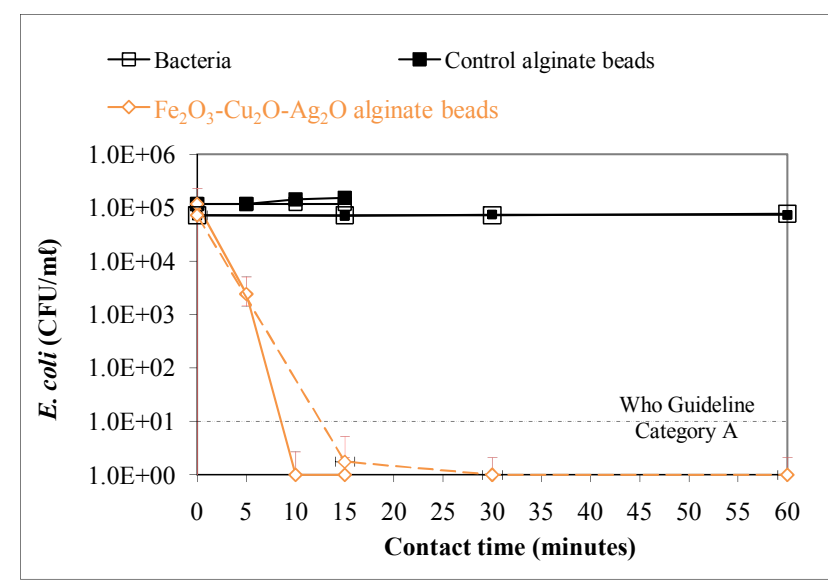

Figure 4

Inactivation of E. coli by alginate beads containing 3 metal oxides

0, 15 and $30 \mathrm{~min}(---)$ and $0,5,10$ and $15 \mathrm{~min}$ (-—)

or by intracellular production as a consequence of the damage that silver causes by forming insoluble complexes with DNA and cellular RNA (Park et al., 2009). This causes the interruption of growth, metabolism and reproduction in the affected cell, as well as changes in structure and permeability of the cell membrane, disturbing the interchange of material between cell and its environment. Silver causes the cytoplasmic membrane to shrink and to separate from the cell wall (Feng et al., 2000).

An increase in the bacterial inactivation effect produced by disinfectants generating reactive oxygen species like $\mathrm{H}_{2} \mathrm{O}_{2}$ and PAA, and $\mathrm{Cu}$ and $\mathrm{Ag}$ in their ionic states, was observed for APT and biological treatment effluents (Orta de Velásquez et al., 2008; Luna-Pabello et al., 2009). In these experiments, the time required to obtain Category A effluents was $30 \mathrm{~min}$ for $\mathrm{H}_{2} \mathrm{O}_{2}-\mathrm{Cu}(50.0-1.0 \mathrm{mg} / \ell), \mathrm{H}_{2} \mathrm{O}_{2}-\mathrm{Ag}(200.0-1.0 \mathrm{mg} / \ell)$ or PAA-Ag $(7.5-1.0 \mathrm{mg} / \ell)$ combinations and was reduced by $10 \mathrm{~min}$ for $\mathrm{Cu}-\mathrm{Ag}$-PAA (0.1-1.0 -20.0 $\mathrm{mg} / \ell)$ combination. That is, these contact times were higher than those required for the combination of the 3 metallic oxides. This supports the theory that oxygen contained in the oxides of the 3 metals used plays an active role in disinfection.

In Fig. 5, an increase in disinfection by using the combination of the 3 metals is observed, where a contact time lower than $5 \mathrm{~min}$. was needed for removing $10^{5} \mathrm{CFU} / \mathrm{m} \ell$ E. coli, while NMA requires $30 \mathrm{~min}$ (Fig. 1). Consequently, combination of the 3 metals is a good option in disinfection of effluents from biological treatment systems, without the presence of undesirable metals such as $\mathrm{Pb}$ and $\mathrm{As}$ (Miranda-Ríos and LunaPabello, 2002-2003).

NMA required a contact time of 30 min (Fig. 1) and AMA required $13 \mathrm{~min}$ (Fig. 4). The E. coli inactivation kinetics followed the Hom equation using either the NMA or the $\mathrm{Fe}_{2} \mathrm{O}_{3}$ $\mathrm{Cu}_{2} \mathrm{O}-\mathrm{Ag}_{2} \mathrm{O}$ AMA and the corresponding equations were: $\mathrm{Nt} /$ $\mathrm{N} 0=\exp \left(-0.1555 \times \mathrm{t}^{1.3327}\right)$ and $\mathrm{Nt} / \mathrm{N} 0=\exp \left(-0.669 \times \mathrm{t}^{1.204}\right)$, respectively. In both cases, it was observed that the inactivation rate increases with the contact time due to the fact that $m$ is greater than 1.0. The rate constant is more than 2 times greater for the AMA than for the NMA, according to its greater disinfectant power.

Also, the NMA rate constant is very close to that measured for the $\mathrm{Cu}-\mathrm{Ag}$ PAA $\left(\mathrm{k}^{*}=-0.1612\right)$ (Luna-Pabello et al., 2009). In both cases, the silver concentration was $1.0 \mathrm{mg} / \ell$ and the initial bacteria concentration was $10^{5} \mathrm{CFU} / 100 \mathrm{~m} \ell$.

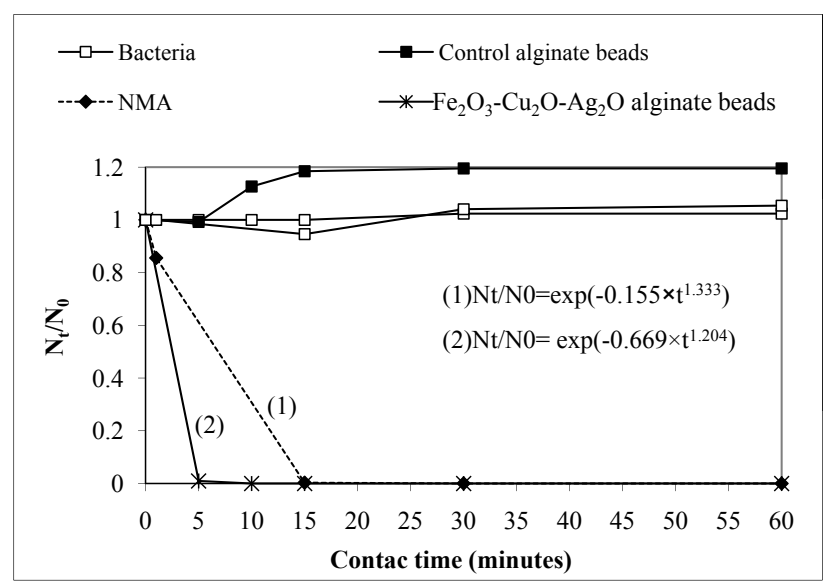

Figure 5

Disinfecting effect of alginate beads simultaneously containing the 3 metal oxides and that obtained

with NMA

In the case of the use of chloramine, at a concentration level of $2.4 \mathrm{mg} / \ell$, to disinfect a biological effluent, a rate constant of -0.361 was measured, which is close to that found for the $\mathrm{Fe}_{2} \mathrm{O}_{3}-\mathrm{Cu}_{2} \mathrm{O}-\mathrm{Ag}_{2} \mathrm{O}$ beads. However, the $m$ exponent for chloramine disinfection $(m=0.715)$ is lower than 1.0 (Pretorius and Pretorius, 1999); that is, the rate decreases with the contact time, which implies that chloramine is in fact consumed during the disinfection. This is in contrast to disinfection with $\mathrm{Fe}_{2} \mathrm{O}_{3}$ $\mathrm{Cu}_{2} \mathrm{O}-\mathrm{Ag}_{2} \mathrm{O}$ beads, for which no metal consumption has been observed.

Moreover, for all tests performed, the $\mathrm{pH}$ was maintained at about 8.5, whereas in the case of dissolved oxygen there was a slight tendency to decrease from 5.6 to $5.1 \mathrm{mg} / \ell \mathrm{O}_{2}$. With regard to redox potential, the value increased by $18.0 \mathrm{mV}$ in assays where $\mathrm{Ag}_{2} \mathrm{O}$ y $\mathrm{Fe}_{2} \mathrm{O}_{3}-\mathrm{Ag}_{2} \mathrm{O}$ was used; by $20 \mathrm{mV}$ for $\mathrm{Cu}_{2} \mathrm{O}-\mathrm{Ag}_{2} \mathrm{O}$ beads; by $34 \mathrm{mV}$ for $\mathrm{Fe}_{2} \mathrm{O}_{3}-\mathrm{Cu}_{2} \mathrm{O}-\mathrm{Ag}_{2} \mathrm{O}$ beads; and by $24 \mathrm{mV}$ for NMA. This increase in redox potential, where the environment becomes more oxidising, can be related to $E$. coli removal, as a greater increase produces a smaller contact time to inactivate the bacteria. For flasks containing alginate beads comprising $\mathrm{Cu}_{2} \mathrm{O}, \mathrm{Fe}_{3} \mathrm{O}_{2}$ and $\mathrm{Fe}_{2} \mathrm{O}_{3}-\mathrm{Cu}_{2} \mathrm{O}$ combination, redox potential was maintained about $8 \mathrm{mV}$. These beads showed very low disinfecting capacity (less than 1 base-10 logarithmic unit).

In Mexico, wastewater is a valuable (and sometimes the only) resource available for crop irrigation, but is frequently reused in agriculture without any proper application of disinfection measures. This inevitably poses a grave risk to health. Therefore, the importance of this type of study lies in the priority it attaches to treating the high levels of microbial contamination which exist in wastewater, when said wastewater is destined for reuse in agriculture (Orta de Velásquez et al., 2008).

Chlorination is the wastewater disinfection method more widely used, even though it might lead to the formation of trihalomethanes and organochlorinated compounds which are carcinogens. The main alternatives to chlorination are ozonation, and the use of ultraviolet light. According to estimates carried out by Collivignarelli et al. (2000), the investment cost for the disinfection of wastewater previously treated by a biological system varies, depending on the size of the plant, as follows (in South African Rands): Chlorine dioxide = ZAR138 427 to 1993 343; ozone = ZAR346 067 to 5613 198; ultraviolet light $=$ ZAR263 010 to 7336609 . Another possible 
technical alternative for the disinfection of raw or partially treated wastewater is the use of metals such as silver $(\mathrm{Ag})$ and copper $(\mathrm{Cu})$. However, there is little information available on this subject.

It should be noted that as the wastewater moves forward in the treatment train its faecal coliform content as well as its nutritional content diminishes. For this reason, if the adequate disinfection of wastewater at the early stages of the treatment is achieved using low concentrations of metals, it would be possible to preserve the nutrients and this would represent an advantage when used in agricultural irrigation, while avoiding the creation of carcinogenic compounds associated with the addition of chlorine (Keraita et al., 2008; Luna-Pabello et al., 2009). Before widespread application can be recommended, however, economic feasibility studies need to be conducted. Nevertheless, the alternative remains potentially interesting for developing countries.

\section{Conclusions}

In the case of NMA, for alginate beads containing $\mathrm{Ag}_{2} \mathrm{O}$ and combinations of $\mathrm{Fe}_{2} \mathrm{O}_{3}-\mathrm{Ag}_{2} \mathrm{O}$ and $\mathrm{Cu}_{2} \mathrm{O}-\mathrm{Ag}_{2} \mathrm{O}, 30 \mathrm{~min}$ of contact time were required for inactivating $100 \%$ of $E$. coli at a concentration of $10^{5} \mathrm{CFU} / \mathrm{m} \ell$. For beads containing the $\mathrm{Fe}_{2} \mathrm{O}_{3}-\mathrm{Cu}_{2} \mathrm{O}-\mathrm{Ag}_{2} \mathrm{O}$ mixture 13 min were required. In order to attain Category A water quality, a contact time of 15 to 30 min was required for NMA and $\mathrm{Ag}_{2} \mathrm{O}$ beads, whereas 10 to 15 min was required for $\mathrm{Fe}_{2} \mathrm{O}_{3}-\mathrm{Ag}_{2} \mathrm{O}$ y Cu $\mathrm{Cu}_{2} \mathrm{O}$ $\mathrm{Ag}_{2} \mathrm{O}$ beads. It was observed that redox potential values are closely related to the disinfection level achieved. The need to use less time to achieve the desired disinfection level is closely related to the synergistic effect of the metals present. The observed sequence of decreasing bacterial inactivation effect was as follows: $\mathrm{Fe}_{2} \mathrm{O}_{3}-\mathrm{Cu}_{2} \mathrm{O}-\mathrm{Ag}_{2} \mathrm{O}>\mathrm{Fe}_{2} \mathrm{O}_{3}-\mathrm{Ag}_{2} \mathrm{O}=\mathrm{Cu}_{2} \mathrm{O}$ $\mathrm{Ag}_{2} \mathrm{O}>\mathrm{Ag}_{2} \mathrm{O}=\mathrm{NMA}>\mathrm{Fe}_{2} \mathrm{O}_{3}=\mathrm{Cu}_{2} \mathrm{O}=\mathrm{Fe}_{2} \mathrm{O}_{3}-\mathrm{Cu}_{2} \mathrm{O}$. The advantage of using alginate beads is that it allows the formation of AMA, which has a greater disinfecting capacity than NMA.

\section{Acknowledgements}

The authors acknowledge the financial support of the DGAPA (UNAM) through PAPIIT Project IN215006 and IN107209. Graduate scholarship for MMR was provided by CONACYT. The authors thank the anonymous reviewers for their valuable suggestions that greatly improved the manuscript.

\section{References}

ARANA I, SANTORUM A, MUELA A. and BARCINA I (2000) Effect of disinfection upon dissolved organic carbon (DOC) in wastewater: bacterial biossays. Letters in Appl. Microbiol. 31 157-162.

ARMIENTA MA and GONZÁLEZ-HERNÁNDEZ G (2007) Solidphase control on the mobility of potentially toxic elements in an abandoned lead/zinc mine tailings impoundment, Taxco, Mexico. Appl. Geochem. 22 (1) 109-127.

BLOOMFIELD SF (1991) Methods for assessing antimicrobial activity. In: Denyer SP and Hugo WB (eds.) Mechanisms of Action of Chemical Biocides. Their Study and Exploitation. Society for Applied Bacteriology Technical Series No 27. Blackwell Scientific Publications, Oxford. 1-21.

BRACCINI I and PEREZ S (2001) Molecular basis of $\mathrm{Ca}^{2+}$-induced gelation in alginates and pectins: The egg-box model revisited. Biomacromolecules 2 1089-1096.

CASSELLS JM, YAHYA MT, GERBA CP and ROSE JB (1995) Efficacy of combined system of copper and silver and free chlorine for inactivation of Naegleria fowleri amoebas in water. Water Sci. Technol. 31 119-122.

CHALOUPKA K, MALAM Y and SEIFALIAN AM (2010) Nanosilver as a new generation of nanoproduct in biomedical applications. Trends Biotechnol. 28 (11) 580-588.

CHO KH, PARK JE, OSAKA T and PARK SG (2005) The study of antimicrobial activity and preservative effects of nanosilver ingredient. Electrochim. Acta 51 (5) 956-960.

CHOI O, DENG KK, KIM NJ, ROSS L, SURAMPALLI RY and HU Z (2008) The inhibitory effects of silver nanoparticles, silver ions, and silver chloride colloids on microbial growth. Water Res. 42 3066-3072.

COLLIVIGNARELLI C, BERTANZA G and PEDRAZZANI R (2000) A comparison among different wastewater disinfection systems: Experimental results. Environ. Technol. 21 1-16.

CRAIG M W (2001) Coping with resistance to copper/silver disinfection. Water Eng. Manage. 148 (11) 25-27.

DAVIES RL and ETRIS SF (1997) The development and functions of silver in water purification and disease control. Catalysis Today 36 107-114.

DE LA ROSA-GÓMEZ I, OLGUÍN M and ALCÁNTARA TD (2008) Bactericides of coliform microorganisms from wastewater using silver-clinoptilolite rich tuffs. Appl. Clay. Sci. 45-53.

EATON AD, CLESCERI LS, RICE EW, GREENBERG AE and FRANSON AH (2005) Standard Methods for the Examination of Water and Wastewater, $21^{\text {st }}$ edn. American Public Health Association, Washington DC, USA. 1332 pp.

ESPINOSA E, ARMIENTA MA, CRUZ O, AGUAYO A and CENICEROS N (2009) Geochemical distribution of arsenic, cadmium, lead and zinc in river sediments affected by tailings in Zimapán, a historical polymetalic mining zone of México. Environ. Geol. 58 1467-1477.

FENG QL, WU J, CHEN GQ, CUI FZ, KIM TN and KIM JO (2000) A mechanistic study of the antibacterial effect of silver ions on Escherichia coli and Staphylococcus aureus. J. Biomed. Mater. Res. A. 52 (4) 664-668.

GYÜRÉK LL and FINCH GR (1998) Modeling water treatment chemical disinfection kinetics. J. Environ. Eng. 124 (9) 783-793.

GANGADHARAN D, HARSHVARDAN K, GNANASEKAR G, DIXIT D, POPAT KM and ANAND PS (2010) Polymeric microspheres containing silver nanoparticles as a bacterial agent for water disinfection. Water Res. 44 5481-5487.

HOLT KB and BARD AJ (2005) Interaction of Silver (I) ions with the respiratory chain of Escherichia coli: An electrochemical and scanning electrochemical microscopy study of the antimicrobial mechanims of micromolar $\mathrm{Ag}^{+}$. Biochem. 44 13214-13223.

INOUE Y, HOSHINO M, TAKAHASHI H, NOGUCHI T, MURATA T KANZAKI Y, HAMASHIMA H and SASATSU M (2002) Bactericidal activity of Ag-zeolite mediated by reactive oxygen species under aerated conditions. J. Inorg. Biochem. 92 37-42.

JIANG JQ, WANG S and PANAGOULOPOULOS A (2006a) The explotation of potassium ferrate (VI) as a disinfectant/coagulant in water and wastewater treatment. Chemosphere. 63 212-219.

JIANG JQ, PANAGOULOPOULOS A, BAUER M and PEARCE P (2006b) The application of potassium ferrate for sewage treatment. J Environ. Manage. 79 215-220.

JIANG JQ, WANG S and PANAGOULOPOULOS A (2007) The role of potassium ferrate (VI) in the inactivation of Escherichia coli and in the reduction of COD for water remediation. Desalination 210 266-273.

KAWASHITA M, TODA S, KIM HM, KOKUBO T and MASUDA N (2003) Preparation of antibacterial silver-doped silica glass microspheres. J. Biomed. Mater. Res. 66A (2) 266-274.

KIM J, CHO M, OH B, CHOI S and YOON J (2004) Control of bacterial growth in water using synthesized inorganic disinfectant. Chemosphere 55 775-780.

KIM JY, LEE C, CHO M and YOON J (2008) Enhanced inactivation of E. coli and MS-2 phage by silver ions combined with UV-A and visible light irradiation. Water Res. 42 356-362.

KERAITA B, JIMENEZ B and DRECHSEL P (2008) Extent and implications of agricultural reuse of untreated, partly treated and diluted wastewater in developing countries. CAB Reviews: 
Perspect. Agric., Vet. Sci., Nutr. Nat. Resourc. 3 (58) 1-15.

LIBERTI L, LOPEZ A, NOTARNICOLA M, BARNEA N, PEDAH-

ZUR R and FATTAL B (2000) Comparison of advanced disinfecting methods for municipal wastewater reuse in agriculture. Water Sci. Technol. 42 215-220.

LI Q, MAHENDRA S, LYON DY, BRUNET L, LIGA VM, LI D and ALVAREZ PJJ (2008) Antimicrobial nanomaterials for water disinfection and microbial control: Potential applications and implications. Water Res. 42 4591-4602.

LUKHELE LP, KRAUSEI RWM, MAMBA BB and MOMBA MNB (2010) Synthesis of silver impregnated carbon nanotubes and cyclodextrin polyurethanes for the disinfection of water. Water $S A$ 36 (4) 433-436.

LUNA-PABELLO VM, MIRANDA-RÍOS M, JIMÉNEZ B and ORTA $\mathrm{T}$ (2009) Effectiveness of the use of $\mathrm{Ag}, \mathrm{Cu}$ and PAA to disinfect municipal wastewater. Environ. Technol. 30 (2) 129-139.

METCALF E and EDDY C (2004) Wastewater Engineering: Treatment and Reuse ( $4^{\text {th }}$ edn.). McGraw Hill, Washington DC, USA. $1819 \mathrm{pp}$.

MIRANDA-RÍOS M and LUNA-PABELLO VM (2002-2003) Eliminación de Escherichia coli de aguas residuales pretratadas biológicamente empleando Terreros de minas de plata. Anuario Latinoamericano de Educación Química (ALDEQ). San Luis Argentina. XVI (XVI) 247- 250.

MILAN, Z, DE LAS POZAS C, CRUZ M, BORJA R, SANCHEZ E, ILANGOVAN K, ESPINOSA Y and LUNA B (2001) The removal of bacteria by modified natural zeolites. J Environ. Sci. Health A 36 (6) 1073-1087.

ORTA DE VELÁSQUEZ MT, YÁÑEZ-NOGUEZ I, JIMÉNEZCISNEROS B and LUNA-PABELLO VM (2008) Adding silver and copper to hydrogen peroxide and peracetic acid in the disinfection of an advanced primary treatment effluent. Environ. Technol. 29 (11)1209-1217.

PARK HG, KIM TW, CHAE MY and YOO IK (2007) Activated carbon-containing alginate adsorbent for the simultaneous removal of heavy metals and toxic organics. Process Biochem. 42 1371-1377.

PARK HJ, KIM JY, KIM J, LEE JH, HAHN JS, GU M B and YOON J (2009) Silver-ion-mediated reactive oxygen species generation affecting bactericidal activity. Water Res. 43 1027-1032.

PEDAHZUR R, LEV O, FATTAL B and SHUVAL HI (1995) the interaction of silver ions and hydrogen peroxide in the inactivation of $E$. coli: A preliminary evaluation of a new long acting residual drinking water disinfectant. Water Sci. Technol. 31 123-129.
PRETORIUS PC and PRETORIUS WA (1999) Disinfection of purified sewage effluent with monochloramine. Water SA 25 (4) 463-47.

RIVERA-GARZA M, OLGUÍN MT, GARCÍA-SOSA I, ALCÁNTARA D and RODRÍGUEZ-FUENTES G (2000) Silver supported on natural Mexican zeolite as an antibacterial material. Microporous Mesoporous Mater. 39 431-444.

ROHR U, WEBER S, SELENKA F and WILHELM M (2000) Impact of silver and copper on the survival of amoebae and ciliated protozoa in vitro. Int. J. Hyg. Environ. Health 203 (1) 87-89.

ROMERO FM, ARMIENTA MA, GUTIÉRREZ ME and VILLASEÑOR G (2008) Factores geológicos y climáticos que determinan la peligrosidad y el impacto ambiental de jales mineros. Rev. Int. Contam. Ambient. 24 (2) 43-54.

SCHINK T and WAITE TD (1980) Inactivation of $\mathrm{f} 2$ virus with Ferrate (VI). Water Res. 14 1705-1717.

SHARMA KV, KAZAMA F, JIANGYONG H and RAY AK (2005) Ferrates (iron(VI) and iron (V)): Environmentally friendly oxidants and disinfectants. J. Water Health. 3 (11) 45-58.

SILVA-MARTÍNEZ S, ALVAREZ-GALLEGOS A and MARTÍNEZ E (2004) Electrolytically generated silver and copper ions to treat cooling water: an environmentally friendly novel alternative. Int. J. Hydrogen Energ. 29 921-932.

SMEDLEY PL (2008) Sources and distribution of arsenic in groundwater and aquifers. In: Appelo T (ed.) Arsenic in Groundwater: A World Problem. Proc. Seminar, Utrecht, 29 November 2006. Netherlands National Committee of the IAH (International Association of Hydrogeologists). 4-32.

SILVESTRY-RODRIGUEZ N, SICAIROS-RUELAS EE, GERBA P $\mathrm{CH}$ and BRIGHT KR (2007) Silver as a disinfectant. Rev. Environ. Contam. Toxicol. 191 23-45.

WHO (1989) Health Guidelines for the Use of Wastewater in Agriculture and Aquaculture, Technical Report Series No. 778. World Health Organization, Geneva.

YAMANAKA M, HARA K and KUDO J (2005) Bactericidal actions of silver ion solution on Escherichia coli, studied by energyfiltering transmission electron microscopy and proteomic analysis. Appl. Environ. Microb. 71 (11) 7589-7593.

YI Y, WANG Y and LIU H (2003) Preparation of new crosslinked chitosan with crown ether and their adsorption for silver ion antibacterial activities. Carbohydr. Polym. 53 425-430.

YOU Y, HAN H, CHIU PC and JIN Y (2005) Removal and inactivation of waterbone viruses using zerovalent iron. Environ. Sci. Technol. 39 9263-9269. 